\title{
SUCCESSFUL LONG-DISTANCE AERIAL TRANSPORT OF FERTILIZED SHEEP OVA
}

\author{
G. L. HUNTER, G. P. BISHOP, \\ C. E. ADAMS AND L. E. ROWSON \\ University of Natal, Pietermaritzburg, South Africa, and \\ A.R.C. Unit of Reproductive Physiology and Biochemistry, \\ University of Cambridge
}

\section{(Received 16th September 1961)}

\begin{abstract}
Summary. Two experiments were carried out involving the exportation by air from Great Britain of a total of three rabbit does carrying in their oviducts fertilized sheep ova for transfer to recipient ewes in South Africa. In October, 1960, ova were recovered in Cambridge from Border Leicester ewes which had been mated to a ram of the same breed. The ova were transported in two does to Pietermaritzburg, where they were transferred to Dorper ewes. In the second experiment early in December, 1960, fertilized ova were recovered from Welsh Mountain ewes (after they had been mated to Welsh Mountain rams) and finally transferred to German Merino ewes in South Africa. Following storage periods in the rabbits ranging (in the two experiments) from 101 to $128 \mathrm{hr}$, seventeen sheep blastocysts or late morulae were recovered in Pietermaritzburg and sixteen were transferred to a total of ten recipient ewes. Six pregnancies resulted and four live lambs were born to foster mothers in South Africa. The techniques are described in detail.
\end{abstract}

\section{INTRODUCTION}

This work was suggested by Averill, Adams \& Rowson (1955), who reported that, following transfer to the genital tract of the rabbit, fertilized sheep ova can survive for at least 5 days and develop to the early blastocyst stage. The survival rate of the sheep ova during storage in the rabbit was rather better than that reported later for sheep ova stored in vitro for 3 days at 4.5 to $7 \cdot 0^{\circ} \mathrm{C}$ (Averill \& Rowson, 1959). Marden \& Chang (1952) described the successful aerial transport of fertilized rabbit ova stored in a thermos flask. Storage time in their experiment was $27 \mathrm{hr}$ and the temperature in the thermos had risen to $19^{\circ} \mathrm{C}$ at the time of unpacking. Clearly, the use of a rabbit as an 'incubator' at present offers the best prospect of successful long distance aerial transport of fertilized sheep ova.

Air transport costs for a single rabbit are low enough to make the long distance movement of livestock in this way an economic proposition. From London to Durban in Natal, for example, a charge of about $f^{8}$ for carriage of a 
crated $2.5 \mathrm{~kg}$ rabbit is made at present. The cost of transporting an adult sheep by sea from Great Britain to South Africa might be as much as $£ 80$, while these charges in the case of cattle (to which species our techniques might in future be extended) may be in the vicinity of $£ 200$ per head. The experiments reported here are the first in which the fertilized ova of farm animals have been transported in this way and subsequently developed to term.

\section{MATERIAL AND METHODS}

PLAN OF PROCEDURE

In each experiment, the dates of departure of suitable flights from London Airport determined the timing of the operations at each stage. During the periods in which the experiments were to be conducted, an air freighter was due to leave London at 2.30 a.m. on Sundays and the dates 23rd October and 4th December were selected for the departure from London. To allow time for post-operative recovery of the rabbit, the transfer of ova to the does in Cambridge was originally planned, in both experiments, for the Friday prior to the departure of the flight. In order that 4- to 8-cell sheep ova might be recovered on the Friday morning in each case, it was necessary for the donor ewes to ovulate some 24 to $30 \mathrm{hr}$ previously, i.e. late on Wednesday or early on Thursday morning. On the assumption that ovulation would occur about the end of oestrus and that the latter would last approximately $24 \mathrm{hr}$, the start of oestrus in the donor ewes in Cambridge as well as in the recipient ewes in South Africa was planned for Wednesday morning, 19th October (Experiment 1) and Tuesday afternoon, 29th November (Experiment 2).

In both experiments, the oestrous cycles of the donor and recipient ewes were synchronized by means of daily injections of progesterone in arachis oil. Oestrus in the donor ewes in Cambridge was to occur during the normal autumn breeding season and synchronization at this time of year is straightforward (Hunter, 1954). In South Africa, many of the more popular breeds of sheep have breeding seasons that enable some of them to be mated in spring and early summer, particularly if the ewes have been kept on a high plane of nutrition during the previous winter (Hunter, 1961). Dorper ewes, a hardy local mutton breed developed in South Africa from crosses between the Dorset Horn and the Blackhead Persian, were available as prospective recipients for the first experiment in October and German Merinos for the second experiment in December. Synchronization during the early summer of the oestrous cycles of both these breeds had been found previously to be satisfactory (Lishman \& Hunter, 1961). Because their cycle lengths are usually about 17 to 19 days, progesterone treatment of the ewes in South Africa continued for 21 days in each case and the timing of the whole synchronization treatment, particularly that of the last progesterone injection, was ultimately determined by the expected time of departure of the selected flight.

The donor ewes in Cambridge were primed with a total of $100 \mathrm{mg}$ of a horse anterior pituitary preparation, AP118B, to induce superovulation. This was given subcutaneously in five equal doses at 12-hourly intervals, commencing 
at different stages in the two experiments (see later). The techniques employed for the in vivo recovery of ova from the donor ewes in Cambridge and transfer to the recipient ewes in South Africa have been previously described (Hunter, Adams \& Rowson, 1955).

The rabbits to which the sheep ova were to be transferred were given an ovulating injection (25 i.u. LH, 'Pregnyl', Organon) about $24 \mathrm{hr}$ before the transfer operation. Preliminary experiments had shown that 2- to 8-cell sheep ova could survive for 4 to 5 days in the ligated oviduct of the rabbit (Adams \& Rowson, 1960 - unpublished data) and since a greater proportion of ova are generally recovered from the oviduct than from the uterus, immediately prior to transfer of the ova to the does their oviducts were ligated near the tubouterine junction. After arrival in Pietermaritzburg, the does were killed and the oviducts excised for flushing. Sterile sheep blood serum was used at all stages of the experiments in the processes of recovery and transfer of the ova. The rabbit carcases were incinerated shortly afterwards, thus satisfying an important condition of the Veterinary Import Permit issued in South Africa.

\section{Experiment 1}

As their oestrous cycles were already fairly well synchronized, it was not necessary to administer progesterone for a long period to the six Border Leicester donor ewes in Cambridge. Three of the ewes received eight and three only seven daily injections of $10 \mathrm{mg}$ progesterone, the last in each case being administered at about 11 a.m. on 15th October. Twenty-four hours later, treatment of these ewes with anterior pituitary extract was commenced. The ewes were then run with a raddled, fertile Border Leicester ram; two were served during 17 th October and the remaining four between 5 p.m. on 17th October and $8 \mathrm{a} . \mathrm{m}$. the following morning. In the meantime, the Dorper ewes in South Africa received daily injections of $10 \mathrm{mg}$ progesterone from 26th September and for the last time at about 2 p.m. on 16th October. By the use of vasectomized rams, the ewes were thereafter tested every $2 \mathrm{hr}$ for oestrus until the display in all cases was over. Of the nineteen treated ewes, fourteen commenced oestrus between 2 a.m. and 2 p.m. on Wednesday, 19th October. Two more came into oestrus by midnight and the remaining three on 20th October. Oestrus continued in these ewes for 14 to $34 \mathrm{hr}$ (mean $24 \cdot 1 \pm 1 \cdot 4 \mathrm{hr}$ ).

Ovum recovery was performed in Cambridge on Thursday afternoon, 20th October, instead of Friday 21 st as planned. This was necessary as the prospective donor ewes had commenced oestrus rather earlier than expected. This fact possibly also explains the low ovulation rate: sixteen ova (three 1-cell, two 4-cell and eleven 8-cell) were recovered from the six Border Leicester ewes, which had a total of only eighteen ovulations. After recovery had been carried out on each ewe, the ova were stored in dialysis chambers at $37^{\circ} \mathrm{G}$ (Averill \& Rowson, 1958) until sufficient had accumulated for transfer to a rabbit. All the ova were transferred to two rabbits, the thirteen cleaved ova being divided between three oviducts, whilst the three 1-cell ova (these were probably unfertilized) were transferred to the remaining oviduct. The details of recoveries and transfers are given in Table 1.

Information regarding the numbers and stages of ova transferred to each 
TABLE

THE TIMING OF RECOVERIES AND TRANSFERS OF

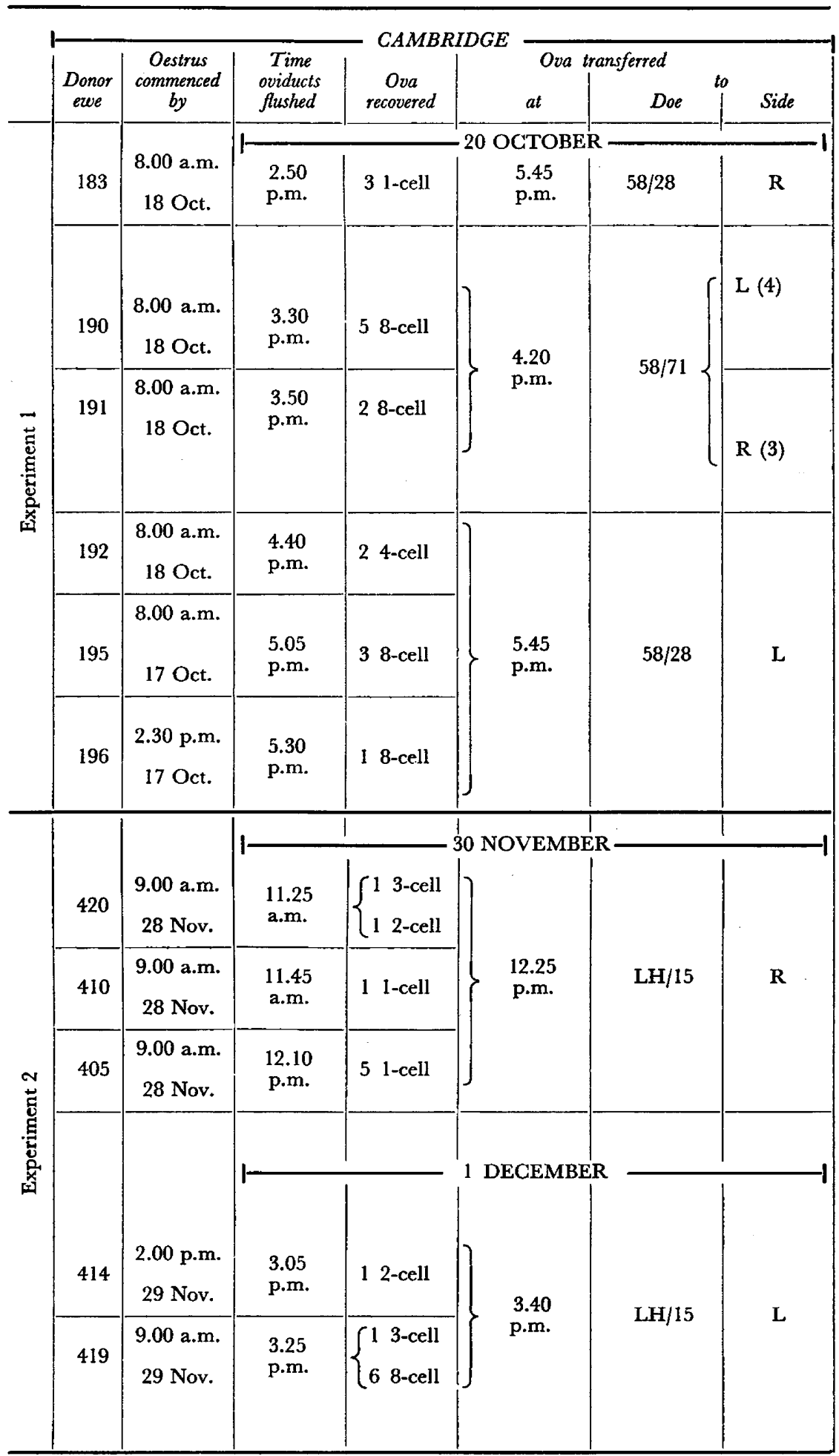




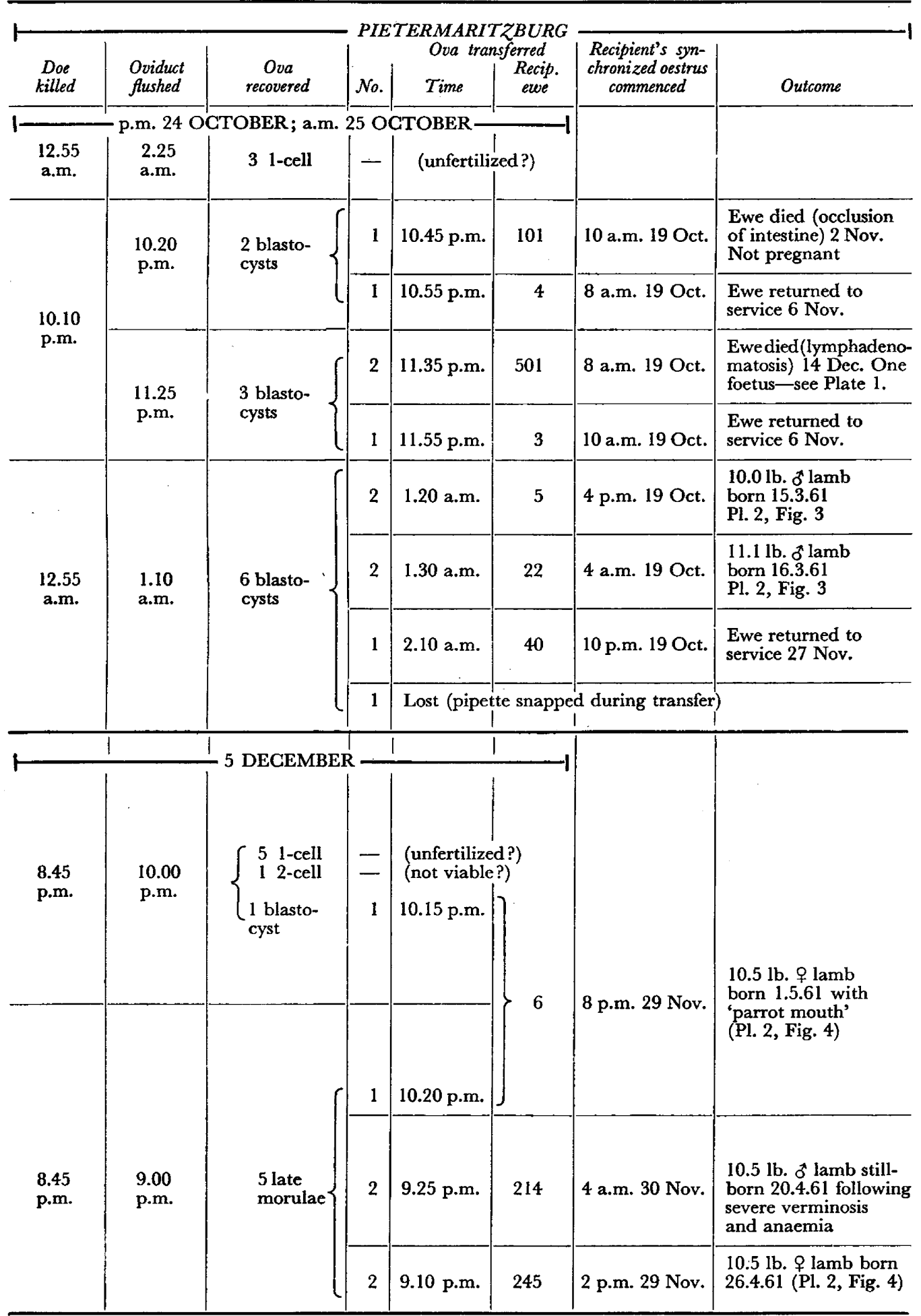

time in Pietermaritzburg was $2 \mathrm{hr}$ ahead of Greenwich time. 
oviduct of the two rabbits were sent by airmail and received in Pietermaritzburg on Monday, 24th October. From among the sixteen ewes that had commenced oestrus on 19th October, eight in good condition, which had records of good fertility - i.e. had lambed regularly each year - were then selected and prepared for the transfers, the intention being to transfer not more than two ova to each recipient ewe. In the meantime, the rabbits were flown from London Airport as arranged, met at Durban Airport on Monday evening, 24th October, and brought 60 miles by car to the Ukulinga Experiment Station, Pietermaritzburg, where they finally arrived at 11.30 p.m. local time (9.30 p.m. G.M.T.).

Recovery of the ova from the first rabbit, 58/71, commenced shortly after midnight, local time (shown in Table 1 as 10.10 p.m. G.M.T.). After the right oviduct and uterine horn had been placed in a covered watchglass in an incubator set at $38^{\circ} \mathrm{C}$, the left oviduct was dissected out and flushed. Two sheep blastocysts were located, one being transferred to the uterine horn of Dorper ewe No. 101 and one to ewe No. 4. The two remaining ova, which had been originally transferred to the rabbit's left oviduct, were not recovered. During the intervals between location and transfer, the watchglasses containing the ova were kept, as far as possible, covered in the incubator. The right oviduct, after storage in the incubator for an hour, was then similarly dissected and flushed and three blastocysts were located $80 \mathrm{~min}$ after slaughter of the rabbit. The details of their transfer to recipient ewes, together with those of the recoveries from the second rabbit and transfers of these ova to recipient ewes are given in Table 1. The times of commencement of oestrus in associated donor and recipient ewes are also shown in the Table. Because the ova recovered from two or three donor ewes were accumulated and transferred together to one rabbit oviduct, it is not possible to follow precisely the fate of ova from individual ewes. However, the origins or fates of groups of ova may be traced in the Table.

\section{Experiment 2}

The synchronization treatment of five Welsh Mountain ewes in Cambridge consisted of sixteen daily injections of $15 \mathrm{mg}$ progesterone, the last being administered at about 11 a.m. on 25th November. The priming injections in this experiment commenced simultaneously with the end of the progesterone treatment. Subsequent services by raddled, Welsh Mountain rams were recorded daily at approximately 9 a.m., 2 p.m. and 5 p.m. (Table 1). The prospective recipient ewes in Pietermaritzburg (German Merinos) were given, from 6th November, twenty-one daily injections of $10 \mathrm{mg}$ progesterone, the last being at about 5.30 p.m. on 26th November, and were then teased by vasectomized rams at 2-hourly intervals. One of the twenty ewes showed no sign of oestrus following this synchronization treatment. Oestrus commenced in two ewes between $4 \mathrm{a} . \mathrm{m}$. and $8 \mathrm{a}$.m. on Tuesday, 29th November; between 2 p.m. and 10 p.m. eleven ewes first accepted service and the remaining six were picked out by the teaser rams by 4 p.m. on 30th November. The mean length of oestrus in the German Merino ewes was $18.9 \pm 1.4 \mathrm{hr}$, some $5 \mathrm{hr}$ less than in the Dorpers in the first experiment. 

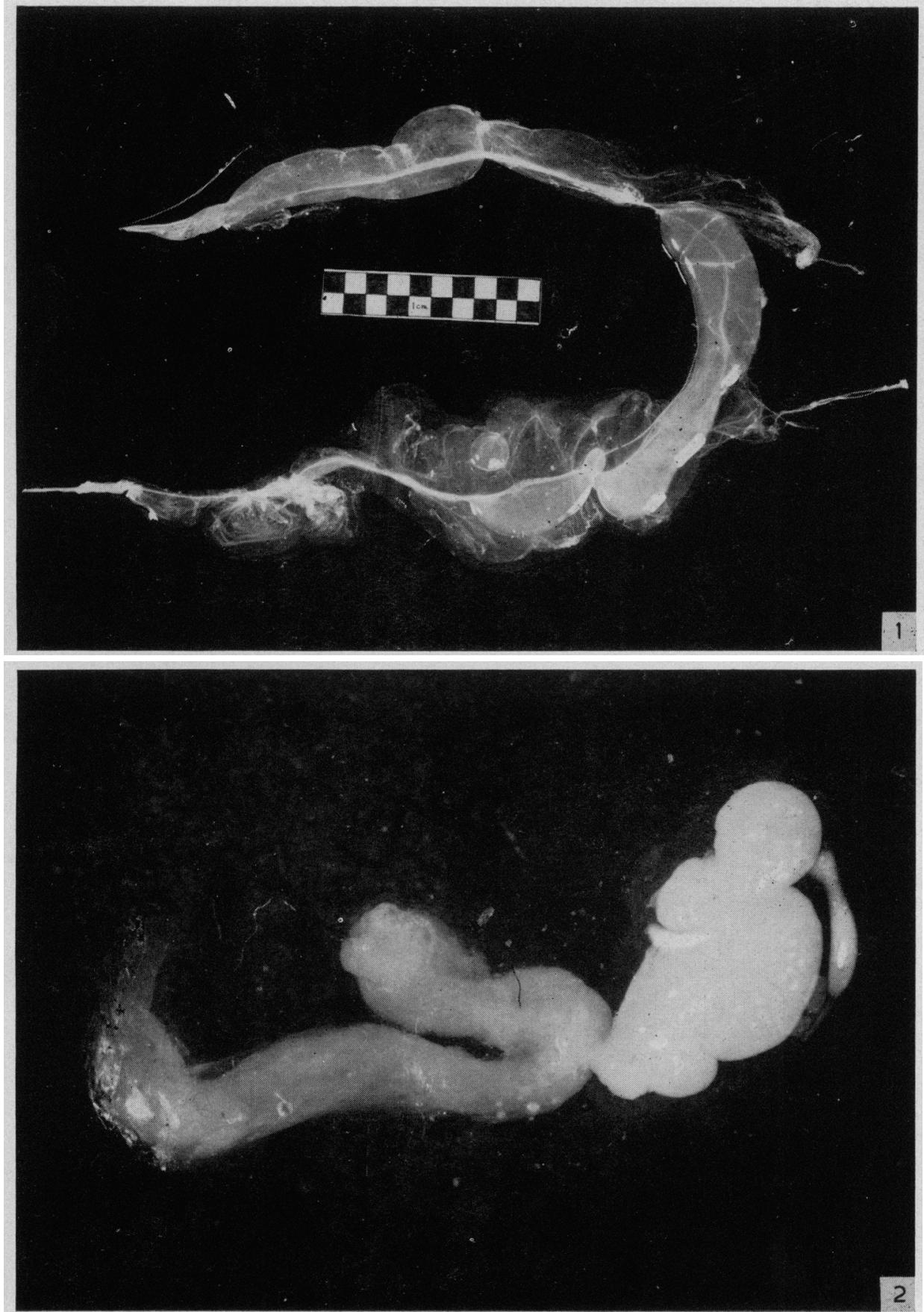

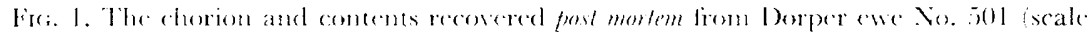

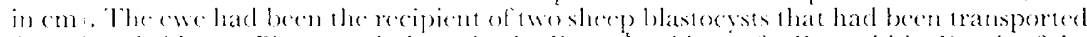

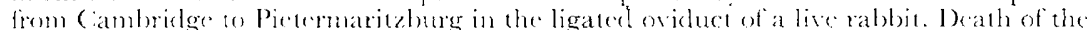

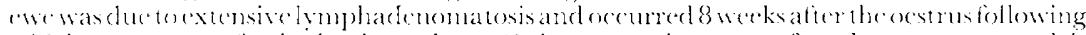

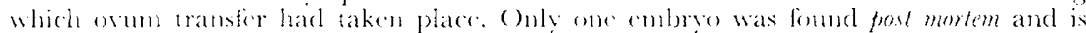
ckarly visible withen the ammion. The embryo itself, apparenty degenerating, is shown

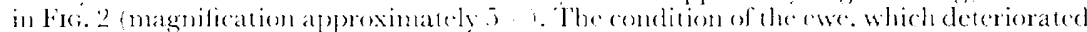

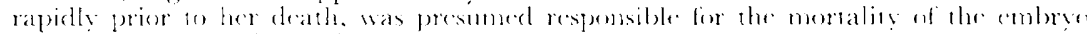
afier it had survied transter. 
PLATE 2
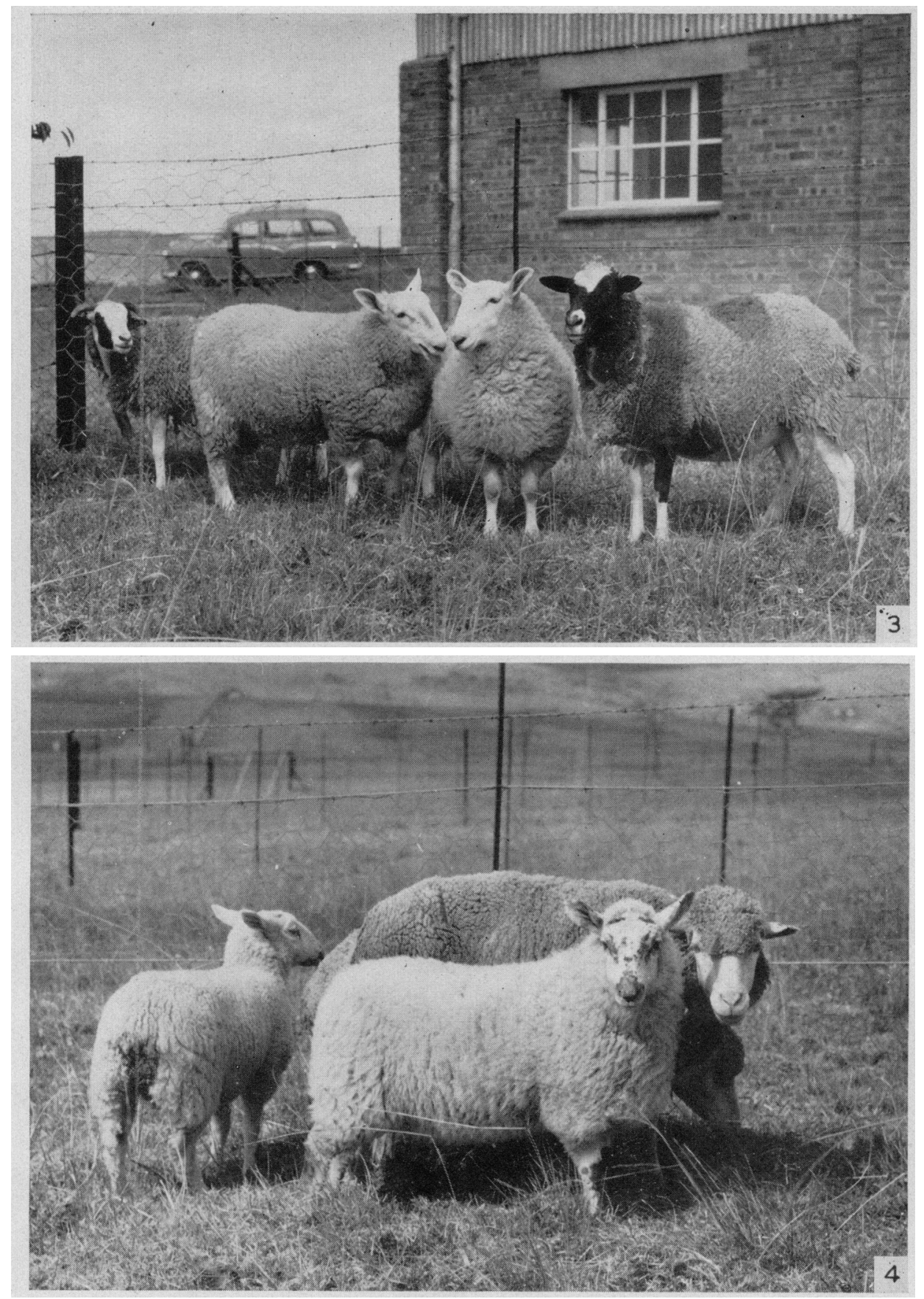

lambs bom in South Africa following their importation from Great Britain as fertilized ova. The ova were transported from Cambridge to Pievermaritzburg in the ligated oriducts of live rabbits and transferred on arrival to the uteri of local ewes, shown here with the lambs. FIr. 3. Two 5-month-old Border Leicester ram lambs (in the centre) with the Dorper ewes that reared them from the blastocyst stage. Fic. 4. Two 31-month-old Welsh Mountain ewe lambs with their German Merino foster mothers'. The short or 'undershot' mandibles (parrot mouth' of the smaller lamb on the left made both suckling and eating difficuli for the lamb. 
Because of the extent of the variation in time of onset of oestrus in the donor ewes, on 30th November ova were recovered from three ewes and transferred to the right oviduct of a doe and on the following day ova from two more ewes were transferred to the left oviduct of the same rabbit (Table I). Whereas in the first experiment unexpectedly low ovulation rates occurred in the donor ewes, in Experiment 2 a high percentage of the ova recovered was not fertilized. As in Experiment 1, the recovered ova were stored in dialysis chambers until transfer to a ligated oviduct of the rabbit.

As before, advice concerning the ova carried by the rabbit was received in Pietermaritzburg on the Monday (5th December) and sufficient German Merino ewes were selected from among those with synchronized oestrous cycles. The rabbit arrived early that evening and the records of ova recovered and transferred are given in Table 1 .

\section{RESULTS AND DISGUSSION}

The pregnancies resulting from these transfers are indicated in the Table. In the first experiment, the sheep ova remained in the oviducts of the rabbits for approximately 102 and $103 \mathrm{hr}$. Fourteen out of a total of sixteen ova were recovered from the two does and ten of the eleven that had continued cleavage, apparently normally, to the early blastocyst stage were transferred to seven Dorper ewes, three of which became pregnant, two eventually lambing. In the second experiment, five out of eight ova were recovered after storage in the doe's left oviduct for $101 \mathrm{hr}$ and seven out of eight after storage in the right oviduct for about $128 \mathrm{hr}$. At least two pregnancies followed transfer of ova recovered from the doe's left oviduct, but it is not possible to state whether it was the blastocyst recovered from the right oviduct or the fifth morula from the left oviduct which survived storage and transfer to Ewe 6 . However it may be possible to determine the parents of this lamb by blood grouping and in the future such tests may be essential if it is required to establish for stud-book purposes the parentage of animals born to foster mothers following their transfer as fertilized ova.

For efficient application of these techniques, methods for reducing the vulnerability of the ova during the two in vitro storage periods are necessary. The use, for example, of the dialysis chamber (Averill \& Rowson, 1958), or simply of small stoppered tubes (Hancock \& Hovell, 1961), for storage of the ova between killing of the rabbit and transfer to the recipient ewes, as well as during the period following recovery from the donor ewes, appears to be preferable to the covered watchglasses employed in these experiments. Presumably more lambs can be expected per rabbit if the ova can survive longer intervals of in vitro storage during this second period, or, alternatively, if the rate of laparotomies and transfers of ova to recipients can be increased. In these experiments the number of ova transferred to the rabbits was governed by the number of suitable ova recovered from donor ewes. If, however, the supply of ova is not a limiting factor, the number that can be transported per rabbit and survive transfer to recipients will be limited in practice by their survival following recovery from the rabbit and pending transfer to the recipient 
ewes. The upper limit to the number of ova that will survive mere simultaneous storage in one rabbit remains to be determined.

These techniques are likely to be of value in cases where the importation of exotic breeds is desirable and either the cost of transportation is prohibitive, or, more particularly, where for reasons of disease control the importation of farm animals cannot be permitted. Livestock transported as embryos are not at present subject to a costly period of quarantine, but may instead, as a result of being reared by a foster mother adapted to local conditions, have the advantage of receiving some degree of passive immunity to some of the diseases of their new environment. Furthermore, some of the difficulties of acclimatization, with which adult stock imported into a new environment are faced, may also be reduced in this way. These two possibilities appear to merit investigation. On the other hand, an importer of pedigree livestock who employs these methods will, for the time being, have no say as to the sex of the imported animals and his choice in the first place will be limited to the selection of sire and dam.

\section{ACKNOWLEDGMENTS}

These experiments were financed jointly by the Agricultural Research Council of Great Britain and the South African Department of Agricultural Technical Services. We are grateful to Dr T. Mann for his encouragement and guidance, to the staffs of the Animal Research Station, Cambridge, and the Ukulinga Experiment Station, Pietermaritzburg, and to Dr D. J. le Roux and the many other persons who assisted us in various ways. Thanks are also due to $\mathrm{Mr} \mathrm{J}$. Schoonraad for the photographs accompanying this paper.

\section{REFERENCES}

Averill, R. L. W., Adams, G. E. \& Rowson, L. E. A. (1955) Transfer of mammalian ova between species. Nature, Lond. 176, 167.

Averitl, R. L. W. \& Rowson, L. E. A. (1958) Ovum transfer in the sheep. F. Endocrin. 16, 326.

Averill, R. L. W. \& Rowson, L. E. A. (1959) Attempts at storage of sheep ova at low temperatures. 7. agric. Sci. 52, 392.

Hancock, J. L. \& Hoveld, G. J. R. (1961) Transfer of sheep ova. F. Reprod. Fertil. 2, 295.

HUNTER, G. L. (1954) Attempts to synchronize the occurrence of oestrus in sheep as a preliminary to ovum transplantation. 7. Endocrin. 10, xiii.

Hunter, G. L. (1961) Some effects of the plane of nutrition on the occurrence of oestrus in Merino ewes. Proc. IVth int. Congr. Anim. Reprod., The Hague, sect. Physiol.

Hunter, G. L., Adams, C. E. \& Rowson, L. E. (1955) Inter-breed ovum transfer in sheep. F. agric. Sci. 46, 143.

Lishman, A. W. \& Hunter, G. L. (1961) Synchronization of the oestrous cycle in sheep. 2. Administration of progesterone daily or at three-day intervals. S. Afr. F. agric. Sci. 4, 35.

Marden, W. G. R. \& Chang, M. C. (1952) The aerial transport of mammalian ova for transplantation. Science, $115,705$. 